\title{
Identification of Antibiotic Clarithromycin Binding Peptide Displayed by T7 Phage Particles
}

\author{
Tetsuro Morimura, Naoko Noda, Yasutaro Kato, Tetsuaki Watanabe, Takeki Saitoh, \\ Takayuki Yamazaki, Keiichi Takada, Satoko Aoki, Keisuke Ohta, Masahiko Ohshige, \\ Kengo Sakaguchi, Fumio Sugawara
}

Received: May 15, 2006 / Accepted: September 25, 2006

(C) Japan Antibiotics Research Association

\begin{abstract}
Peptide libraries displayed by T7 phage, which contain random cDNA fragments insets, were screened for their ability to bind to a biotinylated derivative of clarithromycin. Phage particles bound to an immobilized derivative of the antibiotic were isolated and the inserted cDNA was amplified and sequenced. A common selected peptide sequence, composed of 19 amino acids, was obtained and a synthetic peptide with this sequence was produced. Surface plasmon resonance experiments showed that the synthetic peptide immobilized on a sensor chip bound to clarithromycin and the dissociation constant was determined to be $2.1 \times 10^{-3} \mathrm{M}$. The dissociation constants of other macrolide antibiotics, erythromycin, roxithromycin, azithromycin and josamycin were also determined to be $5.4 \times 10^{-3} \mathrm{M}, 6.2 \times 10^{-5} \mathrm{M}, 1.1 \mathrm{M}$ and $3.4 \times 10^{-2} \mathrm{M}$, respectively. These results indicated that $\mathrm{T} 7$ phage display method might be useful to determine relatively weak interactions between small molecule drugs and the selected peptides which could represent a possible binding site conserved in binding proteins.
\end{abstract}

Keywords phage display, macrolide antibiotics, clarithromycin, surface plasmon resonance

F. Sugawara (Corresponding author), T. Morimura, N. Noda, Y. Kato, T. Watanabe, T. Saitoh, T. Yamazaki, K. Takada, S. Aoki, K. Ohta, M. Ohshige, K. Sakaguchi: Genome and Drug Research Center, Department of Applied Biological Science, Tokyo University of Science, Noda, Chiba 278-8510, Japan, E-mail: sugawara@rs.noda.tus.ac.jp

\section{Introduction}

It is currently of great interest to identify proteins that interact with small molecules, which will help us understand mammalian biochemical processes and possibly accelerate the development of novel pharmaceutical and agricultural agents [1 3]. One of the latest methods to identify small molecule-binding proteins is "phage display" reported by Smith and Petrenko [4, 5]. For example, affinity selection of a random library of peptides displayed on M13 bacteriophage was performed to identify paclitaxel (Taxol)binding anti-apoptotic human protein Bcl-2, which has no significant sequence homology to that of tubulin [6]. Another interesting example used a T7 phage library of human liver cDNA to show that the anthracyclin antibiotic doxorubicin (brand name: Adriamycin), a widely used antineoplastic agent for solid tumors, binds to a nucleolus phosphoprotein hNopp140 [7].

Clarithromycin (CLA; chemical name-6-O-methylerythromycin, 1) [8] is a macrolide antibiotic that is widely used in clinical medicine. Macrolide antibiotics such as CLA specifically bind to the 50S subunit of the bacterial ribosome thereby interfering with protein biosynthesis [9]. However, the identity of human proteins that bind CLA remains uncertain. If $\mathrm{T} 7$ phage library could display CLAbinding peptides, the amino acid sequences might be conserved in a domain of CLA-binding proteins. To identify CLA-binding amino acid sequences, we used two T7 phage libraries containing cDNA fragment inserts from either human leukocytes or Drosophilae which display exhibiting random peptides on the capsid protein. Phage clones expressing a common peptide were selectively 
amplified after biopanning with a biotinylated derivative of CLA. Using this technique we have identified a 19 amino acid clarithromycin-binding peptide. Furthermore, the dissociation constants between the synthetic peptide and CLA (1), erythromycin (ERY, 2), roxithromycin (RXM, 3), azithromycin (AZM, 4) or josamycin (JSM) were obtained from surface plasmon resonance analyses.

\section{Experimental}

\section{Materials}

ERY (2) was purchased from Sigma-Aldrich (St. Louis, MO). Other macrolide antibiotics, CLA (1), RXM (3), AZM (4) and JSM, were extracted from tablets using $\mathrm{CH}_{2} \mathrm{Cl}_{2}$ and then purified by silica gel column chromatography. The structure of each macrolide and synthetic derivative was checked by both NMR (AVANCE DRX-400 and 600, Bruker BioSpin, Rheinstettin, Germany) and ESI-MS (Esquire3000 plus, Bruker Daltonics, Bremen, Germany). Chemical shifts in the NMR data were expressed by $\delta$ ppm from TMS as an internal standard. All NMR and MS data were processed with XWIN-NMR and Data Analysis, respectively. MS of the recombinant protein was determined on a MALDI-TOFMS (Reflex IV, Bruker Daltonics). Surface plasmon resonance data was collected on a Biosensor BIAcore3000 instrument (Uppsala, Sweden). Research grade streptavidin sensor chips were purchased from BIAcore (Sweden). DNA sequences were analyzed using an ABI PRISM ${ }^{\mathrm{R}} 3100$ Genetic Analyzer (Applied Biosystems, Foster City, CA). Unless stated otherwise, all other reagents were of analytical grade and were purchased from Junsei Ltd. (Tokyo, Japan).

\section{Synthesis of Biotinylated CLA (6)}

$N$-Carbobenxyloxy- $\beta$-L-alanine ( $90 \mathrm{mg}, 0.4 \mathrm{mmol}$ ), 1 -(3dimethylaminopropyl)-3-ethylcarbodiimide hydrochloride (EDCI, $100 \mathrm{mg}, 0.52 \mathrm{mmol}$ ) and 4-dimethylamino pyridine (DMAP, $6 \mathrm{mg}, 0.05 \mathrm{mmol}$ ) were added to a solution of CLA $(1,200 \mathrm{mg}, 0.26 \mathrm{mmol})$ in dry pyridine $(10 \mathrm{ml})$, and the mixture was stirred for 5 days at $50^{\circ} \mathrm{C}$. The reaction mixture was poured into water and extracted with ethyl acetate. After being dried over anhydrous $\mathrm{Mg}_{2} \mathrm{SO}_{4}$, the filtrate was evaporated in vacuo to give a syrup and then subjected to silica gel column chromatography to yield $5(55.3 \mathrm{mg}, 0.058 \mathrm{mmol}, 22.3 \%)$. A positive ESI-MS of 5 showed $m / z 953.5$ as an $\mathrm{M}+\mathrm{H}$ ion of $\mathrm{C}_{49} \mathrm{H}_{81} \mathrm{~N}_{2} \mathrm{O}_{16}$. NMR $\left(\mathrm{CDCl}_{3}\right)$; macrolide part, ${ }^{1} \mathrm{H}: \delta 5.05(1 \mathrm{H}, \mathrm{dd}, J=2.32$, $11.12 \mathrm{~Hz}, \mathrm{H}-13), 3.74(1 \mathrm{H}, \mathrm{d}, J=7.28 \mathrm{~Hz}, \mathrm{H}-3), 3.72(1 \mathrm{H}$, d, $J=7.8 \mathrm{~Hz}, \mathrm{H}-10), 3.61(1 \mathrm{H}, \mathrm{d}, J=6.56 \mathrm{~Hz}, \mathrm{H}-5), 3.02$
(3H, s, H-22), 2.97 (1H, m, H-9), $2.83(1 \mathrm{H}, \mathrm{dq}, J=7.28$, $9.12 \mathrm{~Hz}, \mathrm{H}-2), 2.58(1 \mathrm{H}, \mathrm{m}, \mathrm{H}-8), 1.96(1 \mathrm{H}, \mathrm{m}, \mathrm{H}-14 \mathrm{~b})$, $1.88(1 \mathrm{H}, \mathrm{m}, \mathrm{H}-4), 1.68$ (1H, m, H-7b), $1.61(1 \mathrm{H}, \mathrm{m}, \mathrm{H}-7 \mathrm{a})$, $1.50(1 \mathrm{H}, \mathrm{m}, \mathrm{H}-14 \mathrm{a}), 1.41(3 \mathrm{H}, \mathrm{s}, \mathrm{H}-18), 1.21(3 \mathrm{H}, \mathrm{d}$, $J=9.12 \mathrm{~Hz}, \mathrm{H}-16), 1.13$ (3H, d, $J=7.24 \mathrm{~Hz}, \mathrm{H}-19), 1.11$ $(3 \mathrm{H}, \mathrm{d}, J=6.88 \mathrm{~Hz}, \mathrm{H}-20), 1.10(3 \mathrm{H}, \mathrm{s}, \mathrm{H}-21), 0.84(3 \mathrm{H}, \mathrm{t}$, $J=7.6 \mathrm{~Hz}, \mathrm{H}-15), 0.84(3 \mathrm{H}, \mathrm{d}, J=7.6 \mathrm{~Hz}, \mathrm{H}-17),{ }^{13} \mathrm{C}: \delta$ 221.1 (C-9), 175.1 (C-1), 80.8 (C-5), 78.2 (C-6 and C-3), 74.6 (C-13), 74.2 (C-12), 69.1 (C-11), 50.5 (C-22), 45.2 (C-8), 45.0 (C-2), 38.7 (C-7), 38.0 (C-4), 19.8 (C-18), 21.0 (C-14), 10.6 (C-15), 15.9 (C-16), 17.9 (C-19), 16.1 (C-21), $12.3(\mathrm{C}-20), 8.9(\mathrm{C}-17)$; cladinose part, ${ }^{1} \mathrm{H}: \delta 4.79(1 \mathrm{H}, \mathrm{dd}$, $\left.J=7.44,10.68 \mathrm{~Hz}, \mathrm{H}-2^{\prime}\right), 4.60\left(1 \mathrm{H}, \mathrm{d}, J=7.44 \mathrm{~Hz}, \mathrm{H}-1^{\prime}\right)$, $3.50\left(1 \mathrm{H}, \mathrm{m}, \mathrm{H}-5^{\prime}\right), 2.61\left(1 \mathrm{H}, \mathrm{m}, \mathrm{H}-3^{\prime}\right), 2.15$ (6H, s, H-7' and $\left.\mathrm{H}-8^{\prime}\right), 1.75\left(1 \mathrm{H}, \mathrm{m}, \mathrm{H}-4^{\prime} \mathrm{a}\right), 1.24(3 \mathrm{H}, \mathrm{d}, J=6.04 \mathrm{~Hz}$, $\left.\mathrm{H}-6^{\prime}\right), 1.23\left(1 \mathrm{H}, \mathrm{m}, \mathrm{H}-4^{\prime} \mathrm{b}\right),{ }^{13} \mathrm{C}: \delta 100.3\left(\mathrm{C}-1^{\prime}\right), 71.5$ $\left(\mathrm{C}-2^{\prime}\right), 68.3\left(\mathrm{C}-5^{\prime}\right), 63.8\left(\mathrm{C}-3^{\prime}\right), 39.7\left(\mathrm{C}-7^{\prime}\right.$ and $\left.8^{\prime}\right), 28.22$ $\left(\mathrm{C}-4^{\prime}\right), 21.5\left(\mathrm{C}-6^{\prime}\right)$; desosamine part, ${ }^{1} \mathrm{H}: \delta 4.92(1 \mathrm{H}, \mathrm{d}$, $\left.J=4.48 \mathrm{~Hz}, \mathrm{H}-1^{\prime \prime}\right), 3.95$ (1H, dq, $J=6.32,6.24 \mathrm{~Hz}, \mathrm{H}-5^{\prime \prime}$ ), $3.32\left(3 \mathrm{H}, \mathrm{s}, \mathrm{H}-8^{\prime \prime}\right), 3.05\left(1 \mathrm{H}, \mathrm{dd}, J=8.88,8.88 \mathrm{~Hz}, \mathrm{H}-4^{\prime \prime}\right)$, $2.36(1 \mathrm{H}$, br s, H-2"a), $1.61(1 \mathrm{H}, \mathrm{dd}, J=4.52,2.28 \mathrm{~Hz}, \mathrm{H}-$ $\left.2^{\prime \prime}\right), 1.29$ (3H, d, $\left.J=6.24 \mathrm{~Hz}, \mathrm{H}-6^{\prime \prime}\right), 1.25$ (3H, s, H-7"), ${ }^{13} \mathrm{C}$ : $\delta 95.9\left(\mathrm{C}-1^{\prime \prime}\right), 77.8\left(\mathrm{C}-4^{\prime \prime}\right), 72.9\left(\mathrm{C}-3^{\prime \prime}\right), 65.9\left(\mathrm{C}-5^{\prime \prime}\right), 49.4$ $\left(\mathrm{C}-8^{\prime \prime}\right), 21.5\left(\mathrm{C}-7^{\prime \prime}\right), 18.6\left(\mathrm{C}-6^{\prime \prime}\right)$.

The solution of 5 ( $46 \mathrm{mg}, 0.048 \mathrm{mmol})$ in ethanol $(20 \mathrm{ml})$ was stirred for 2 hours at room temperature in the presence of $10 \% \mathrm{Pd} / \mathrm{C}(10 \mathrm{mg})$ under a hydrogen atmosphere. The reaction mixture was filtered and the filtrate was evaporated in vacuo. The residual oil $(39 \mathrm{mg})$ and 6-(biotinamidocaproylamide)caproic acid $N$-hydroxysuccinimide ester $(30 \mathrm{mg}, 0.05 \mathrm{mmol})$ was dissolved in dry pyridine $(10 \mathrm{ml})$ and stirred for 2 hours at room temperature. The reaction mixture was evaporated in vacuo, and the residue was subjected to silica gel column chromatography to give $6(41.5 \mathrm{mg}, 0.033 \mathrm{mmol}, 69 \%)$. A positive ESI-MS of $\mathbf{6}$ showed $\mathrm{m} / \mathrm{z} 1271.7$ as an $\mathrm{M}+\mathrm{H}$ ion of $\mathrm{C}_{63} \mathrm{H}_{111} \mathrm{~N}_{6} \mathrm{O}_{18} \mathrm{~S}$.

\section{Construction of 77 Phage Library from D. melanogaster} Poly(A)+ RNA, random primers, 5'-methylated dCTP, T4 DNA polymerase, EcoRI/HindIII linkers, EcoRI, HindIII, T7Select10-3b vector and T7 Packaging Extracts were purchased from Novagen (Madison, WI). Aliquots of $80 \mu \mathrm{g}$ of total RNA were extracted from D. melanogaster Kc cells. Oligotex-dt30 〈super〉 (Takara, Kyoto, Japan) was used for a second round of isolation with minimal loss of material to produce poly(A)+ RNA suitable for random primed cDNA synthesis. cDNA synthesis was primed with $4 \mu \mathrm{g}$ of $\operatorname{poly}(\mathrm{A})+\mathrm{RNA}$ with random primers, and then $5^{\prime}-$ methylated dCTP was incorporated into both strands without extraction or precipitation between the first and 
second strand synthesis. The cDNA were treated with T4 DNA polymerase to generate fragments with blunt ends and then ligated with directional EcoRI/HindIII linkers. Following linker ligation, the cDNA was digested sequentially with HindIII and EcoRI then inserted into EcoRI/HindIII digested T7Select10-3b vector arms. The resultant cDNA was inserted into the EcoRI/HindIII site of $\mathrm{T} 7$ phage 10-3B vector and packaged into phage. The titer of this library was $1.6 \times 10^{10} \mathrm{pfu} / \mathrm{ml}$.

\section{Construction of T7 Phage Library from Human Leukocytes}

The HindIII random primer (dTTNNNN), MMLV-RT, methylated dNTPs, E. coli DNA pol I, T4 DNA polymerase and EcoRI/HindIII linker were purchased from Novagen. The T7 phage library displaying alternative peptide sequence was made as follows. A $400 \mu \mathrm{g}$ aliquot of human leukocyte total RNA, extracted by RNeasy Maxi (Qiagen, Amsterdam, The Netherlands), was applied to an oligotexdT30 resin (Takara) to purify poly(A) ${ }^{+}$mRNA. We used $4 \mu \mathrm{g}$ of poly $(\mathrm{A})^{+}$mRNA primed with HindIII random primer (dTTNNNN) for first strand cDNA synthesis using MMLV-RT and methylated dNTPs. Second strand cDNA was synthesized with E. coli DNA pol I. The double stranded cDNA was made flush with T4 DNA polymerase. The blunt-ended double stranded cDNA was ligated with EcoRI/HindIII linker and digested with EcoRI and HindIII. The resultant cDNA was inserted into the EcoRI/HindIII site of T7 phage 10-3b vector and packaged into phage. The titer of the primary recombinants was $4 \times 10^{6} \mathrm{pfu} / \mathrm{ml}$.

\section{Biopanning and Sequence Analysis}

Following four rounds of selection, almost 40 plaques were arbitrarily isolated from LB plates and each was dissolved in phage extraction buffer $(20 \mathrm{mM}$ Tris- $\mathrm{HCl}$, pH 8.0, $100 \mathrm{mM} \mathrm{NaCl}, 6 \mathrm{mM} \mathrm{MgSO}_{4}$ ). In order to disrupt the phage, the extract was heated to $65^{\circ} \mathrm{C}$ for 10 minutes. The phage DNA was then amplified by PCR, using the forward primer (5'-GACTTGGCTCTGGAGCGCGC-3') and the reverse primer (5'-AACCCCTCAAGACCCGTTTA-3'). After amplification, the PCR fragments were purified with ExoSAP-IT (Amersham Biosciences, Uppsala, Sweden) and precipitated by adding $100 \%$ ethanol. The purified PCR fragments were then sequenced. Based on the sequence results, the amino acid sequence displayed on the T7 phage capsid was determined. Candidate clones were amplified and used to check the affinity to the biotinylated derivative of CLA (6).

\section{Surface Plasmon Resonance (SPR)}

Binding analysis between CLA and a synthetic peptide
"NSRMRVRNATTYNS" (AnyGen, Kwang-ju, Korea) was performed using a Biosensor BIAcore instrument (BIAcore 3000, Biacore AB) with a CM5 research grade sensor chip (Biacore AB). The synthetic peptide $(332 \mu \mathrm{g} / \mathrm{ml}, 170 \mu \mathrm{l})$ in coupling buffer $\left(10 \mathrm{mM} \mathrm{Na} \mathrm{CO}_{3} / \mathrm{NaHCO}_{3}, \mathrm{pH} 8.5\right)$ was injected over a CM5 sensor chip at a flow rate of $10 \mu \mathrm{l} /$ minute to capture the peptide on the carboxymethyl dextran matrix of the chip by amine coupling at $25^{\circ} \mathrm{C}$. The surface was activated by injecting a solution containing $0.2 \mathrm{M} \quad N$-ethyl- $N$-dimethylaminopropyl carbodiimide (EDC) and $50 \mathrm{mM} \mathrm{N}$-hydroxysuccinimide (NHS) for 14 minutes. The peptide was injected and the surface was then blocked by injecting $1 \mathrm{M}$ ethanolamine at $\mathrm{pH} 8.5$ for 14 minutes. This reaction immobilized about 4700 response units (RU) of the peptide. Binding analyses of macrolides were performed in running buffer (10 mM HEPES, pH 7.4, $150 \mathrm{mM} \mathrm{NaCl}, 3 \mathrm{mM}$ EDTA, $0.005 \%$ Tween-20, 10\% DMSO) at a flow rate of $20 \mu \mathrm{l} /$ minute at $25^{\circ} \mathrm{C}$. To measure the binding specificity and kinetics for the 19 amino acid peptides, an $80 \mu \mathrm{l}$ solution of CLA $(0,125,250$ and $500 \mu \mathrm{M})$, ERY (1, 2 and $4 \mathrm{mM}), \mathrm{RXM}(0,1,2 \mathrm{mM})$, AZM $(0,1,2,4 \mathrm{mM})$ or JSM $(0,0.5,1,2 \mathrm{mM})$ was injected for 240 seconds. Association and dissociation were each measured for 120 seconds at $20 \mu \mathrm{l} /$ minute. Kinetic parameters were determined using the software BIA evaluation 3.1 (Biacore $\mathrm{AB}$ ).

\section{Results}

\section{Synthesis of Biotinylated Clarithromycin}

A derivative of CLA biotinylated at $\mathrm{C}^{\prime}$ on the carbohydrate ring was prepared from CLA (1, Fig. 1A). There were three synthetic steps to give the biotinylated derivative (6) in $14 \%$ total chemical yield: step 1 , the condensation reaction with CLA and $N$-benzyl- $\beta$-alanine to introduce a linker portion for biotin at $\mathrm{C}^{\prime}$ step 2 , reductive hydrogenation to remove the protective benzyl group step 3: biotinylation with 6-(biotinamidocaproylamido)caproic acid $N$-hydroxysuccinimide ester to yield biotinylated-CLA (6). The condensation reaction (step 1) gave three products that could be separated chromatographically. NMR was used to determine the structure of each compound. The three products were: a disubstituted compound at $\mathrm{C}^{\prime}$ on cladinose and $\mathrm{C}^{\prime \prime}$ on desosamine, and two mono substituted products at $\mathrm{C}^{\prime}$ or $\mathrm{C} 2^{\prime \prime}$. In the NMR data of the mono substituted products, the ${ }^{1} \mathrm{H}$ chemical shift $(2 \mathrm{H}, \delta$ $3.2 \mathrm{ppm}$ from TMS as an internal standard) at $\mathrm{C}^{\prime}$ of CLA shifted to $4.79(2 \mathrm{H})$, whereas those at $\mathrm{C}^{\prime \prime}$ did not shift significantly ( $\delta 1.61$ and 2.36 for each proton signal). In the HMBC experiment, the ${ }^{1} \mathrm{H}$ signal at $\mathrm{C}^{\prime}(\delta$ 4.79) had a 


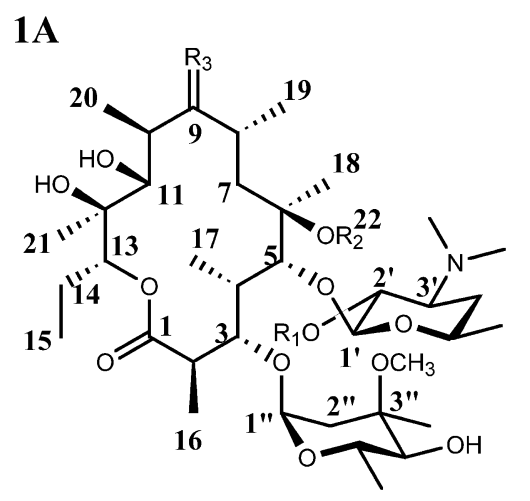

Clarithromycin (1: $\left.\mathrm{R}_{1}=\mathrm{H}, \mathrm{R}_{2}=\mathrm{CH}_{3}, \mathrm{R}_{3}=\mathrm{O}\right)$
Erythromycin $\left(2: \mathrm{R}_{1}=\mathrm{H}, \mathrm{R}_{2}=\mathrm{H}, \mathrm{R}_{3}=\mathrm{O}\right)$
Roxithromycin $\left(3: \mathrm{R}_{1}=\mathrm{H}, \mathrm{R}_{2}=\mathrm{H}, \mathrm{R}_{3}=\mathrm{OCHO}\right.$
1
$\mathrm{~N}$-CBZ- $\beta-\mathrm{Ala}, \mathrm{EDCI}, \mathrm{DMAP}, \mathrm{C}_{5} \mathrm{H}_{5} \mathrm{~N}, \mathrm{rt}$
5: $\mathrm{R}_{1}=\mathrm{COCH}_{2} \mathrm{CH}_{2} \mathrm{NHCBZ}$ (20\%)

a) $10 \% \mathrm{Pd} / \mathrm{C} \mathrm{H}_{2}, \mathrm{C}_{2} \mathrm{H}_{5} \mathrm{OH}, \mathrm{rt}$

b) 6-(biotinamidocaproylamide)caproic acid $N$-hydroxysuccinimide ester, $\mathrm{C}_{5} \mathrm{H}_{5} \mathrm{~N}$, rt<smiles>CC(C)(C)C=O</smiles>

\section{$1 \mathrm{~B}$}

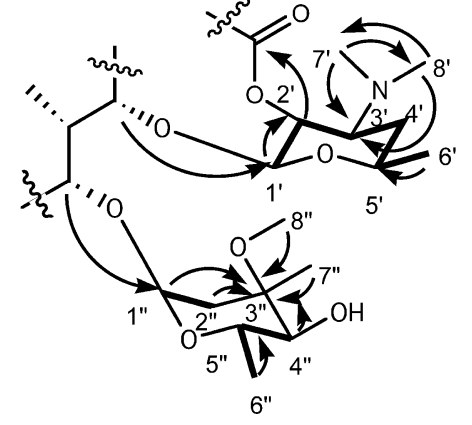

Azithromycin (4)

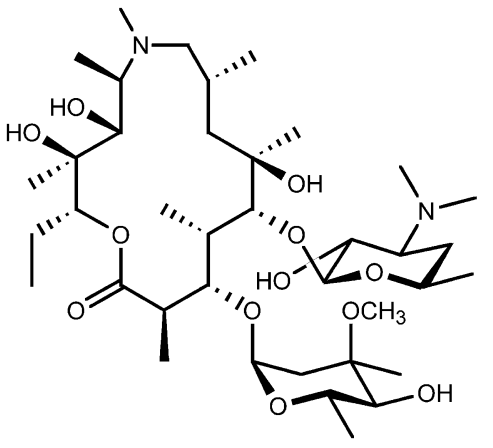



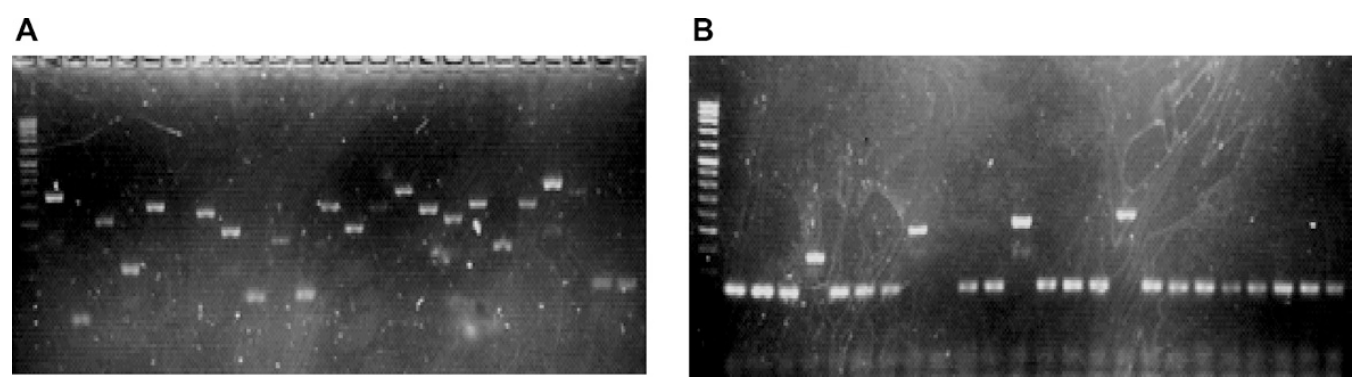

Fig. 2 Agarose gel electrophoretic analyses of the inserted Drosophilae cDNAs in T7 phage selected by biopanning.

A: PCR amplified cDNAs after three rounds, B: PCR amplified cDNAs after four rounds. After four rounds of selection, 89\% of the selected phage exhibited similar-sized bands by agarose gel electrophoresis.

Table 1 The selected peptide and human p8

$\begin{array}{ll}\text { 19aa } & \text { MATFPPATSAPQQPPGPEDEDSSLDESDLYSLAHSYLGGGGRGRTKREAANTNRPSG } \\ \text { P8 } & \\ \text { 19aa } & \text { GISRELVDKLAAALE---- } \\ \text { P8 } & \text { GHERKLVTKLONSERKKRARR } \\ & * . * * * * * \quad: .\end{array}$

The selected 19aa had a sequence similarity with those of human p8 protein residues 58 70 of 82 searched by FASTA program against Swiss Prot protein data base.

to eliminate adventitiously bound clones. The eluted phage were recovered and tested for affinity to biotinylated-CLA (6). Four rounds of biopanning were carried out, and the phage titer determined for the washed and eluted solutions after each round. After the fourth round of panning the ligand-selected and recovered phage represented $0.78 \%$ of the leukocyte library and $0.23 \%$ of the Drosophilae library, whereas the recovered phage from the control was negligible in both cases.

\section{Sequence Analysis of Ligand-selected Phage and Homology Search of Peptide Sequences}

The cDNA inserts from recovered phage were amplified by the polymerase chain reaction (PCR) for analysis by agarose gel electrophoresis and DNA sequencing. After the fourth round of selection (Fig. 2B), the recovered cDNA inserts were much more uniform than the products from the third round (Fig. 2A). In the case of the D. melanogaster phage library, $89 \%$ of the 83 sequenced clones after the fourth round were identified as the same sequence of 57 nucleotides. Furthermore, this was also obtained as a major sequence from the human leukocyte library (i.e. $50 \sim 60 \%$ of sequenced clones). The selected nucleotide sequence and its translation product (NSPAGISRELVDKLAAALE) were screened against the Swiss Prot protein database using the
FASTA program [10]. The search revealed a $66 \%$ similarity (from 13 residues of the query sequence) to a portion of the human $\mathrm{p} 8$ protein (residues $58 \sim 70$ of 82 ) (Table 1). The $\mathrm{p} 8$ protein was found overexpressed in many human cancers [11]. An immunohistochemically investigation of $\mathrm{p} 8$ expression in 50 cases of breast carcinoma indicated that high expression of $\mathrm{p} 8$ was observed in $60 \%$ of cases [12]. In the case of medullay thyroid, $43 \%$ of cases were regarded as high group $\mathrm{p} 8$ expression. The $\mathrm{p} 8$ expression level was directly linked to lymph node metastasis [13]. In addition to those, $\mathrm{p} 8$ is a new target of gemcitabine, the only available chemotherapeutic treatment of pancreatic cancer, in pancreatic cancer cells [14]. There is only presumptive evidence for the relationship of $\mathrm{p} 8$ and CLA yet; however, $\mathrm{p} 8$ could be a candidate for CLA binding target of anti-cancer property from those evidences. Actually, phase II trial of CLA and pamidronate therapy in myeloma has been evaluated [15].

\section{Surface Plasmon Resonance Analysis}

Binding analyses between macrolides and a synthetic peptide (NSPAGISRELVDKLAAALE) were performed by surface plasmon resonance. The synthetic peptide was fixed on a CM5 sensor chip to capture the peptide on the carboxymethyl dextran matrix. The dissociation constants 
CLA

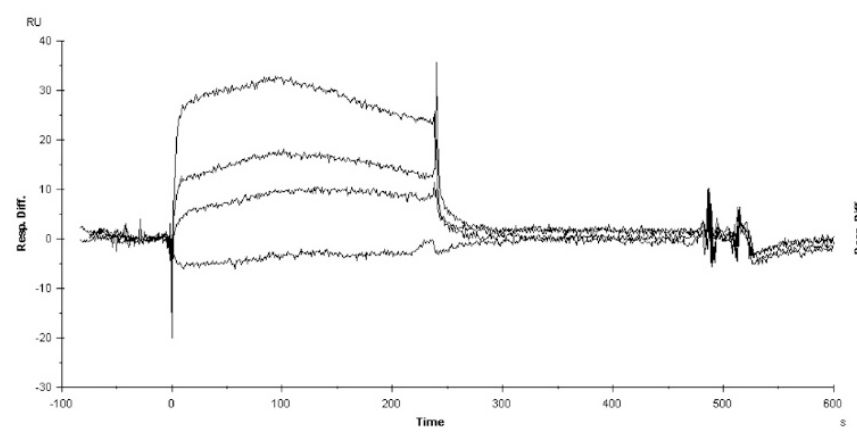

RXM

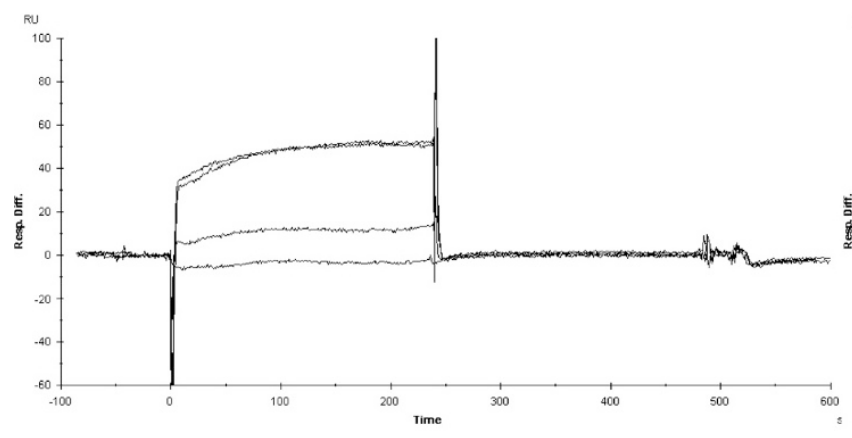

JSM

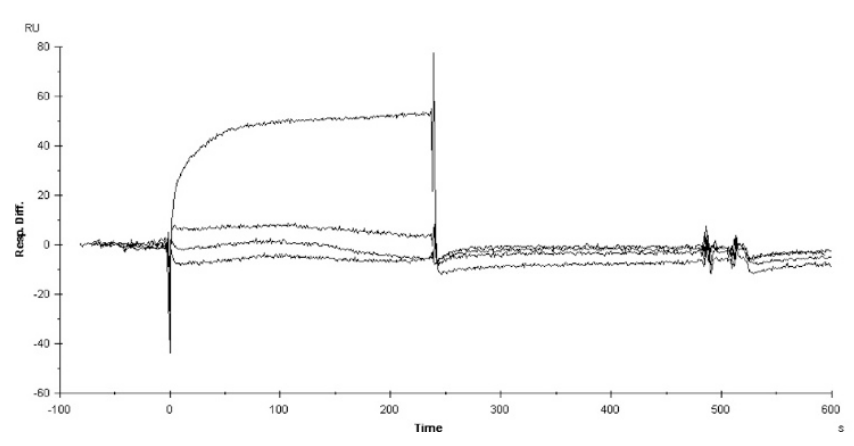

ERY

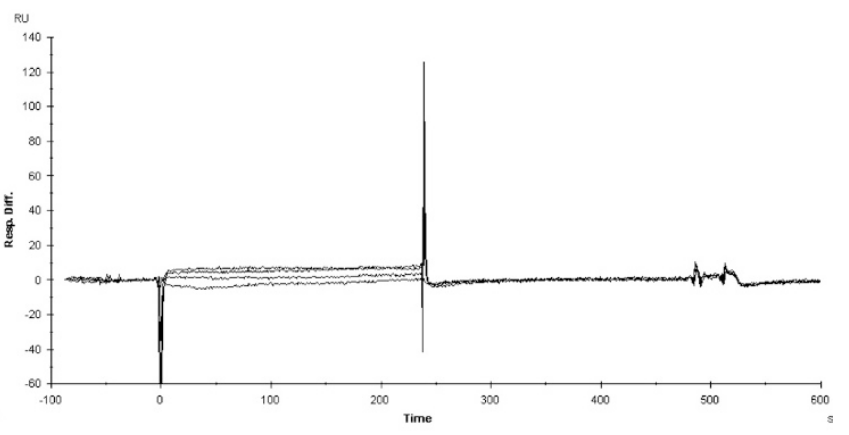

AZM

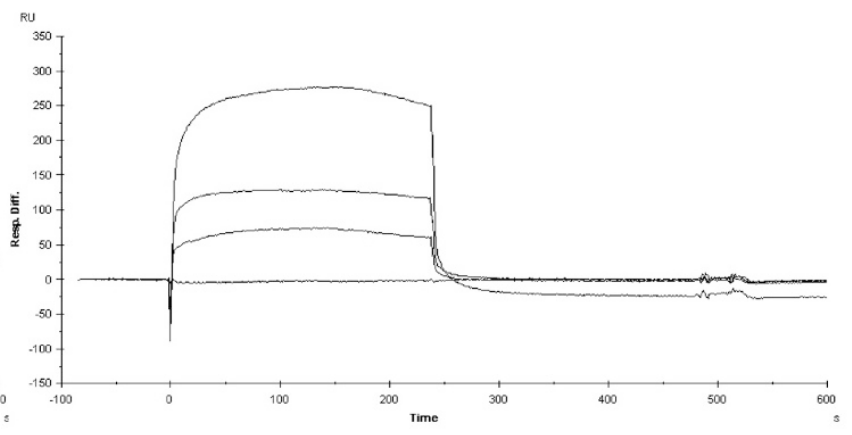

Fig. 3 SPR (BIAcore) analyses of CLA, ERY, RXM, AZM and JSM to the synthetic peptide from T7 phage display libraries.

Bindings of the macrolide antibiotics to the synthetic peptide were detected by surface plasmon resonance (SPR) signals (BIAcore, see Experimental Section), and were indicated in response units. Three different concentrations of each macrolide (see text) were injected over the immobilized peptide (4700 RU) on a CM5 sensor chip for 3 minutes at $20 \mathrm{ml} /$ minute and dissociated for 120 seconds at $20 \mathrm{ml} / \mathrm{minute}$.

$\left(K_{\mathrm{D}}\right)$ of the macrolides with the peptide were determined to be $2.1 \times 10^{-3} \mathrm{M}$ with CLA, $5.4 \times 10^{-3} \mathrm{M}$ with ERY, $6.2 \times 10^{-5} \mathrm{M}$ with RXM, $1.1 \mathrm{M}$ with AZM and $3.4 \times 10^{-2} \mathrm{M}$ with JSM, respectively, using the BIA evaluation 3.1 software (Biacore AB).

\section{Discussion}

The selected nucleotide sequence revealed a similarity to the residues $58 \sim 70$ of 82 amino acids in the human $p 8$ protein (Table 1). The $\mathrm{p} 8$ protein is a small-stress protein involved on several cellular functions including apoptosis. Prothymosin alpha (ProTalpha) and p8 are two natively unstructured proteins with anti-apoptotic activity. Their 
interaction results in the formation of heterodimer complex with stable structure. When Hela cell were treated with staurosporine, the effects of knocking down $\mathrm{p} 8$ and/or ProTalpha or over-expressing $\mathrm{p} 8$ and/or ProTalpha on caspases $3 / 7$ and 9 activities and on cell death were monitored. Transfecting ProTalpha or $\mathrm{p} 8$ small interfering RNAs increased the activities of both caspase and the number of apoptotic nuclei. However, transfecting both small interfering RNAs resulted in no further increase. Over-expressing p8 or ProTalpha did not alter caspase activities, whereas over-expressing both resulted in a significant reduction of caspase activities [16]. Overexpression of was obtained by transfection of apoptotic vectors and inhibition by using specific siRNAs [17]. Inhibition of apoptosis correlated with the level of ProTalpha with lowest concentration, demonstrating that the anti-apoptotic was borne by the complex of p8/ProTalpha, the two proteins, being individually inactive. The stress-regulated protein $\mathrm{p} 8$ (also deigned as candidate of metastasis 1) was also identified as an essential mediator of cannabinoid antitumoral action and show $\mathrm{p} 8$ upregulation is dependent on de novo-synthesized ceramide [18]. It is also observed that $\mathrm{p} 8$ mediates its apoptotic effect via upregulation endoplasmic reticulum stress-related genes ATF-4, SHOP, and TRB3.

We have used a phage display technique to screen for human proteins that specifically bind to CLA. Affinity guided biopanning using biotinylated CLA selected a peptide composed of 19 amino acids. SPR experiments showed that the rank order of affinity is RXM $>$ CLA $>$ ERY $>$ JSM $>$ AZM. The FASTA search revealed a partial similarity to the human $\mathrm{p} 8$ protein (Table 1 ). Human $\mathrm{p} 8$ protein was over-expressed in many human cancers [11], including breast carcinoma [12] and medullay thyroid [13], and also contributes to the metastatic phenotype [18], although its function has not yet been fully elucidated. Thus, if CLA and other macrolides antibiotics could bind to $\mathrm{p} 8$ protein and then interrupt the formation of p8/ProTalpha, it might regulate their apoptotic activity in vivo. Phase II trial of CLA and pamidronate therapy in myeloma [15] could imply the existence of other human proteins that specifically bind to macrolide antibiotics. The binding analyses between human 88 and macrolide antibiotics confirm binding of clarithromycin to $\mathrm{p} 8$ and this will be published elsewhere.

The results obtained here indicated that $\mathrm{T} 7$ phage display method might be useful to determine relatively weak interactions between small molecule drugs and the selected peptides which could also display a possible binding site conserved in binding proteins.
Acknowledgements This work was partially supported by a Grant-in Aid for Scientific Research (The Ministry of Education, Culture, Sports, Science and Technology of Japan).

\section{References}

1. Campbell DA, Szardenings AK. Functional profiling of the proteome with affinity labels. Curr Opin Chem Biol 7: 296-303 (2003)

2. Flaumenhaft R, Derek S, Sim DS. The platelet as a model for chemical genetics. Chem Biol 10: 481-486 (2003)

3. Smith GP. Filamentous fusion phage: novel expression vectors that display cloned antigens on the virion surface. Science 228: 1315-1317 (1985)

4. Smith GP, Petrenko VA. Phage display. Chem Rev 97: 391-410 (1997)

5. Rodi DJ, Janes RW. Sanganee HJ. Holton RA. Wallace BA, Makowski L. Screening of a library of phage-displayed peptides identifies human bcl-2 as a taxol-binding protein. J Mol Biol 285: 197-203 (1999)

6. Jin Y, Yu J, Yu YG. Identification of hNopp140 as a binding partner for doxorubicin with a phage display cloning method. Chem Biol 9: 157-162 (2002)

7. Morimoto S, Misawa Y, Adachi T, Nagate T, Watanabe Y, Ōmura, S. Chemical modification of erythromycins. II. Synthesis and antibacterial activity of $O$-alkyl derivatives of erythromycin A. J Antibiot 43: 286-294 (1990)

8. Morimoto S, Takahashi Y, Watanabe Y, Ōmura S. Chemical modification of erythromycins. I. Synthesis and antibacterial activity of 6-O-methylerythromycins A. J Antibiot 37: 187-189 (1984)

9. Schunzen F, Zarivach R, Harms J., Bachan A, Tocilj A, Albrecht R, Yonath A, Franceschi F. Structural basis for the interaction of antibiotics with the peptidyl transferase centre in eubacteria. Nature 413: 814-821 (2001), and references therein.

10. Pearson WR, Lipman DJ. Improved tools for biological sequence comparison. Proc Natl Acad Sci USA 85: 2444-2448 (1988)

11. Vasseur S, Iovanna JL. Med Sic (Paris) 19: 1259-1264 (1993)

12. Ito $\mathrm{Y}$, Yoshida $\mathrm{H}$, Motoo $\mathrm{Y}$, Iovanna JL, Nakamura $\mathrm{Y}$, Kakudo K, Urono T, Takamura Y, Miya A, Noguchi S, Muma K, Miyauchi A. Expression of p8 protein in breast carcinoma; an inverse relationship with apoptosis. Anticancer Res 25: 833-837 (2005)

13. Ito Y, Yoshida H, Motoo Y, Iovanna JL, Tomoda C, Urono T, Takamura Y, Miya A, Kobayashi K, Matsuzaka F, Muma K, Miyauchi A. Expression of p8 protein in medullary thyroid carcinoma. Anticancer Res 25: 3419-3423 (2005)

14. Giroux V, Malicet C, Barthet M, Gironella M, Archange C, Dagorn JC, Vasseur S, Iovanna JL. p8 is a new target of gemcitabine in pancreatic cancer cells. Clin Cancer Res 12: 235-241 (2006) 
15. Morris TC., Ranaghan L, Morrison J. Phase II trial of clarithromycin and pamidronate therapy in myeloma. Med Oncol 18: 79-84 (2001)

16. Malicet C, Giroux V, Vasseur S, Dagorn JC, Neira JL, Iovanna JL. Regulation of apoptosis by the p8/prothymosin alpha complex. Proc Natl Acad Sci USA 103: 2671-2776 (2006)

17. Malicret C, Dagorn JC, Neira JL, Iovanna JL. The stress- regulated protein p8 mediates cannabinoid-induced apoptosis of tumor cells. Cell Cycle 5: 829-830 (2006)

18. Carracedo A, Lorente M, Egia A, Blazquez C, Garcia S, Giroux V, Malicet C, Villuendas R, Gironella M, GonzalezFeria L, Piris MA, Iovanna JL, Guzman M, Velasco G. The stress-regulated protein $\mathrm{p} 8$ mediates cannabinoid-induced apoptosis of tumor cells. Cancer Cell 9: 301-312 (2006). 